\title{
SiM
}

\section{An Interdisciplinary Approach for Watershed-Scale Assessment and Management}

\author{
By Ryan Martin, Pat Fosse, and Brian Thrift
}

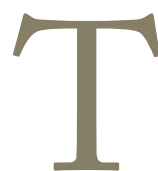

he Bureau of Land Management (BLM) Dillon Field Office (DFO) manages more than 900,000 surface acres of public land in scenic, southwestern Montana. These lands vary from the snow-covered Lima Peaks, near the Idaho border, to the sagebrush-covered, rolling foothills near the first Territorial capital of Bannack, Montana, to the grass-covered lowlands in the Madison Valley. Miles of high-mountain streams-inhabited by native, westslope cutthroat trout-flow down to the sagebrush-dominated grasslands that pygmy rabbits and sage-grouse call home. The sheer beauty and diversity of life within the DFO make managing these public lands for multiple use a privilege and constant challenge.

Healthy lands have always been a priority for BLM's land managers. The challenge, though, has been maintaining healthy public lands while permitting a variety of uses and users on them. Managing BLM lands has continuously evolved since 1946, when the General Land Office and the US Grazing Service merged to form the present day BLM. In 1994, Rangeland Reform attempted to bring change to

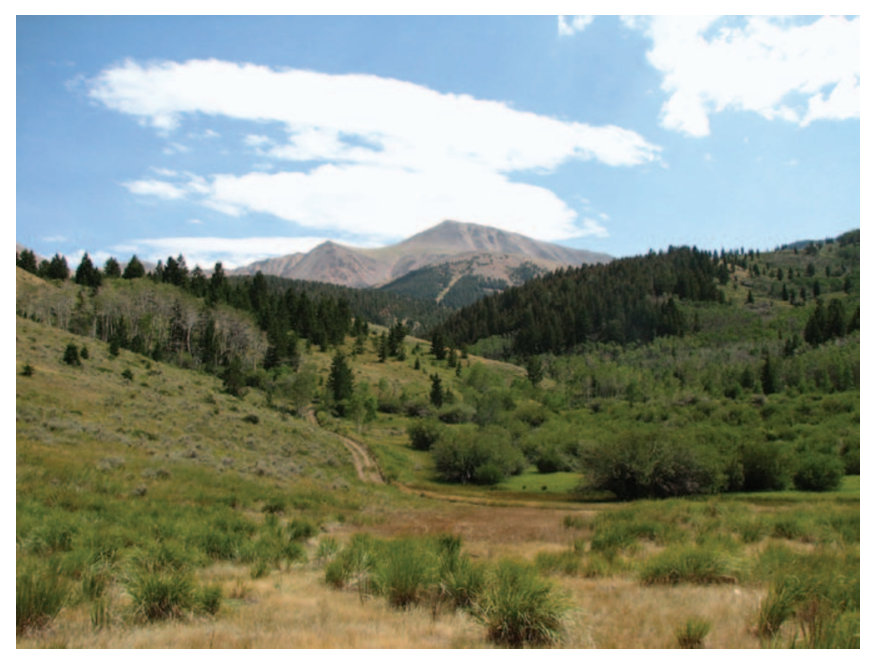

Big Sheep Creek Watershed, July 2004. the BLM's grazing program by addressing the issues of fiscal soundness, public participation in grazing management, and rangeland health. This reform package called for creating citizen-based resource advisory councils (RAC) at the BLM grazing district level and reforming grazing management to improve rangeland health through a series of standards and guidelines aimed at ecosystem management. Rangeland Reform resulted in BLM's adoption of RACs, in all the western states, and the introduction of the Standards for Rangeland Health in 1995, both of which, are still used today. In 1997, the Interior Board of Land Appeals issued the Comb Wash Decision, ${ }^{1}$ which stated that the BLM "did not provide any site-specific environmental analysis of the impact of grazing on the resource values in five canyons on the (Comb Wash) grazing allotment." The decision encouraged BLM to take a more site-specific look at each allotment before renewing term grazing permits. Two years later, in 1999, Congress instructed the BLM to "fully process" all term grazing permits by 2009 , which included assessing rangeland health standards, completing the associated National Environmental Policy Act (NEPA) documentation and changing management to make progress toward meeting Rangeland Health Standards where necessary.

In 2001, BLM issued handbook H-4180 Rangeland Health Standards. ${ }^{2}$ This handbook encouraged BLM to conduct assessments and evaluations to ascertain rangeland health on a watershed basis. It urged that, when an office invests its resources in a Watershed Assessment, the end product should substantially meet all assessment needs to avoid conducting multiple assessments for multiple needs. It also included a flow chart showing the process: Assessment, Evaluation, Determination, Implementation, and Monitoring (adaptive management). The manual was a timely document that outlined a proactive avenue to improve the way BLM does business on public lands. However, adopting this guidance and finding the energy and enthusiasm to change the standard work routine was a commitment that not all BLM field offices welcomed. 


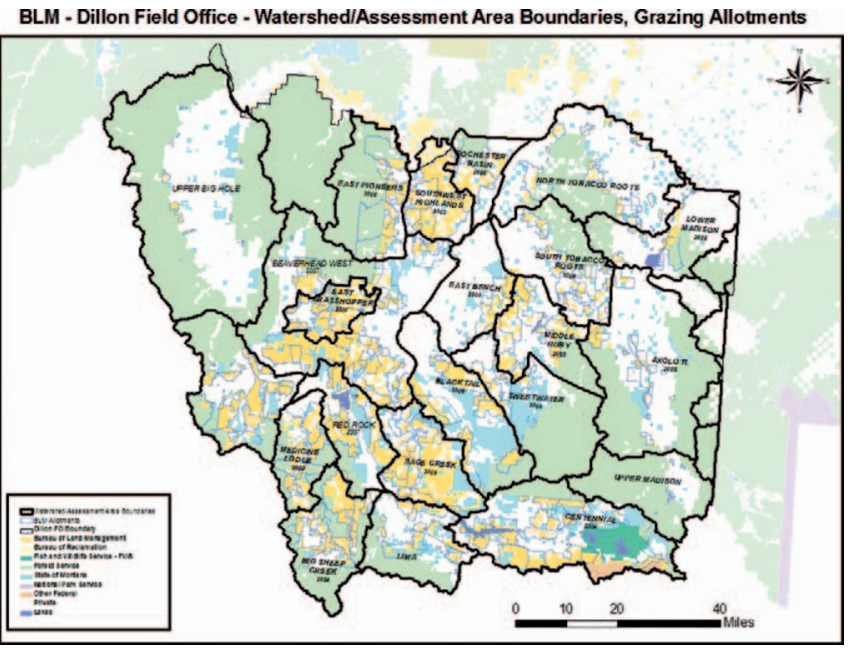

Dillon, Montana, Field Office watershed boundary map.

\section{Dillon, Montana's New Land Health Approach}

In 2001, the DFO was beginning to prepare its new Resource Management Plan (RMP). As part of that effort, the lands administered by the DFO were divided into 17 distinct watersheds. During 2002, the DFO made its first attempt at assessing land health on a watershed basis in the Upper Horse Prairie Watershed. Because the guidance in the 4180 manual $^{2}$ was relatively general, the operational details and specifics needed to be developed. In retrospect, the staff specialists that were assigned to assess the Upper Horse Prairie Watershed started "building the boat as they floated down the river." Previously, the DFO was completing term grazing permit/lease renewals on an allotment-by-allotment basis or grouping them by individual permittees when conducting land health assessments. Assessing land health and renewing term grazing permits/leases by either of these methods proved to be a cumbersome and less-efficient process. The allotment-by-allotment approach had a number of inefficiencies including:

- Less understanding of cumulative effects in the watershed;

- Less knowledge and understanding of other programs' issues and projects;

- Fewer staff participating in on-the-ground assessments, reports, and NEPA documentation;

- Less-efficient management of staff time; and

- Less involvement from other governmental agencies and interested publics.

After the 2002 first attempt at a watershed-scale landhealth assessment, DFO management realized the opportunity to advance the land health and grazing permit renewal approach and began to implement changes that improved land-health assessments. One fundamental change was to integrate all applicable BLM programs into the watershed process. A 10-year plan was developed to assess roughly two watersheds per year and to have all lands administered by the
DFO assessed by the 2009 congressionally mandated deadline. The 10-year cycle would then be repeated to coincide with the 10-year term of the grazing permits/leases. Since 2002, Land Health Assessments, including grazing permit renewals, have been based on fifth-level Hydrologic Unit Code (HUC 5) Watersheds and have been completed on all 17 watersheds within the DFO.

\section{A True Interdisciplinary Team Approach}

Adopting the new Watershed Assessment process does not require any additional positions. What is necessary is reprioritizing each resource specialist's duties and clearly defining his or her role on the interdisciplinary team (IDT) and in the Watershed Assessment process. A critical component of the success of the watershed process is that each fall/winter, DFO Field Manager Tim Bozorth assigns specialists to the IDTs for the upcoming Watershed Assessments scheduled for the following summer. The IDT consists of an IDT Leader and 10-14 core or support specialists representing the primary programs in the office: range, weeds, hydrology, wildlife, fisheries, forestry, fuels, minerals, lands, wilderness, cultural, and recreation. The Field Manager notifies specialists of their assignment with a letter that identifies the exact field assessment dates and critical deadlines throughout the process (e.g., field assessment completion, Watershed Assessment Report, Environmental Assessment [EA], Decisions) with a caveat that, for core IDT members, no requests for regular annual leave will be granted during the scheduled field assessments. The memo clearly states that full participation in field assessments and IDT meetings and in any workload associated with preparing the Watershed Assessment Report and Watershed EA is mandatory. This assignment is also included as a critical element in each of the assigned specialists' Employee Performance Appraisal Plan.

\section{IDT Field Work}

The IDT's goal during field visits is to observe and assess all BLM-administered lands within an assessment area and provide information on the resources to the authorized officer. The authorized officer then makes a determination as to whether the five Montana/Dakotas BLM standards for rangeland health -1) uplands, 2) riparian/wetland, 3) water quality, 4) air quality, and 5) biodiversity - are being met. A particular standard is met if the IDT determines it is in proper functioning condition (PFC) or functioning at risk (FAR) with an upward trend. A standard is not met when conditions are determined to be FAR with a static or downward trend or nonfunctional (NF). Within a single allotment, there are usually a number of upland and riparian areas that are assessed and rated by the IDT. However, only the authorized officer has the authority to determine whether the entire allotment is meeting each of the five standards. To make that final determination, the authorized officer considers individual ratings, site-specific data, recommendations from the IDT, and the scope and scale of the ratings of the various resources within each allotment. 


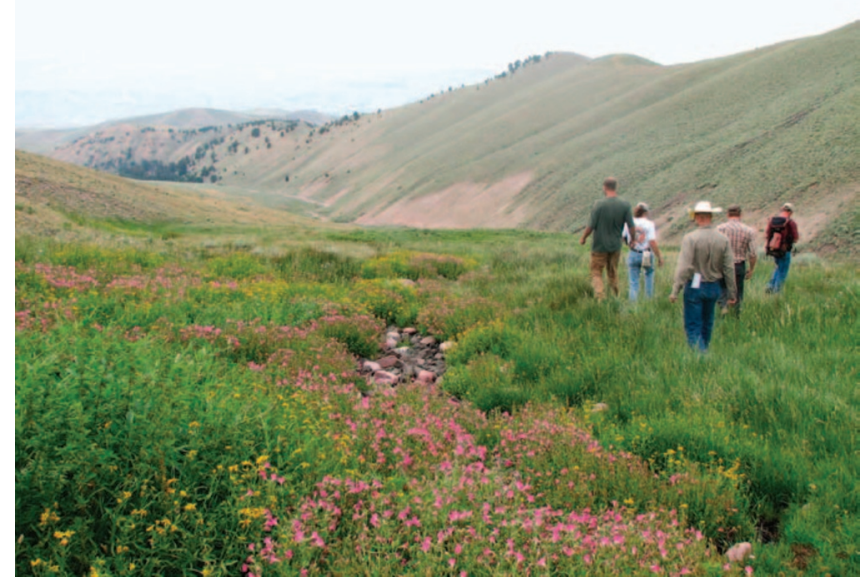

Lima Watershed Assessment interdisciplinary team, July 2007.

During an assessment, the IDT visits all grazing allotments in the Watershed Assessment area. A typical watershed includes 2 to 3 full weeks of field work by the IDT. Upland field visits consist of visiting the upland monitoring sites on each allotment, digging holes to verify soils data, and reviewing all historic monitoring data and photos. Specialists spend time walking key areas of the allotments to better assess upland health and to evaluate range-improvement projects. On historic monitoring sites, specialists evaluate the $17 \mathrm{In}-$ dicators of Rangeland Health, which assess three interrelated components of rangeland health: soil/site stability, hydrological function, and biotic integrity. These help determine whether or not the Upland Standard for Rangeland Health is being met. Each specialist then provides his or her perspective on the upland site's health and whether it is PFC, FAR, or NF. All comments are noted on the evaluation sheet, and all input is documented to finalize the IDT rating of the site's condition. If the rating is FAR, the IDT must determine the site's trend (upward, downward, or static), which helps guide future management changes on the allotment. This process is repeated on all allotments in the field office. During the past decade of completing upland health assessments, more than $90 \%$ of all allotments in the DFO have rated PFC and met the upland health standard.

Upland and riparian/wetland areas are inherently connected. A poorly maintained road, livestock grazing and trailing effects on hillsides, or a decline in forested canopy cover may reduce infiltration and increase runoff, which, in turn, may contribute excessive sediment into a riparian system and prevent it from meeting the riparian standard. Typically, riparian and wetland areas drive management changes on allotments and occupy the largest amount of time during field visits. It has been shown that unmanaged livestock spend a disproportionate amount of time near water sources, so these areas are always a concern for BLM land managers. As with uplands, specialists walk each stream reach or wetland area, review data on the water source, and examine histori- cal photos. A lotic or lentic Riparian Standard Checklist is then completed by the IDT, which poses questions regarding riparian processes and functions. Each IDT member has an opportunity to provide input on these questions and on the riparian area's condition. All input is documented on the form, and individual ratings by IDT members are tallied to rate the riparian health as PFC, FAR, or NF. As with upland sites, a FAR rating requires the IDT to decide the riparian/ wetland area's trend (upward, downward, or static). During the past decade of completing riparian health assessments, about $50 \%$ of all streams in the DFO have not met the riparian health standard. However, management revisions have been implemented on each of those allotments that did not meet the riparian health standard.

The IDT also assesses water quality and air quality within the watershed. Water Quality evaluations are under the jurisdiction of the Montana Department of Environmental Quality, so the IDT's role is to identify areas that are contributing to nonpoint source pollution of streams or wetland areas and to propose range-improvement projects or management changes (e.g., best management practices) that are expected to improve water quality. Air quality is closely associated with burning activities. The Environmental Protection Agency has delegated its authority to implement the provisions of the Clean Air Act to the State of Montana, so determining compliance with air quality standards is the state's responsibility. The IDT is tasked with ensuring that the 1998 Interim Air Quality Policy for wildland and prescribed fires, which requires states to develop smoke management plans, is being followed.

Biodiversity is the standard where the overall health and function of plant and wildlife habitats are assessed. Under this standard, the present state of each habitat type, within each allotment, is compared with the natural and historic condition. During summer site visits, the IDT considers the range of natural variation within the community, as well as the species composition, condition of available habitat, and forest health to determine the condition/function of biodi-

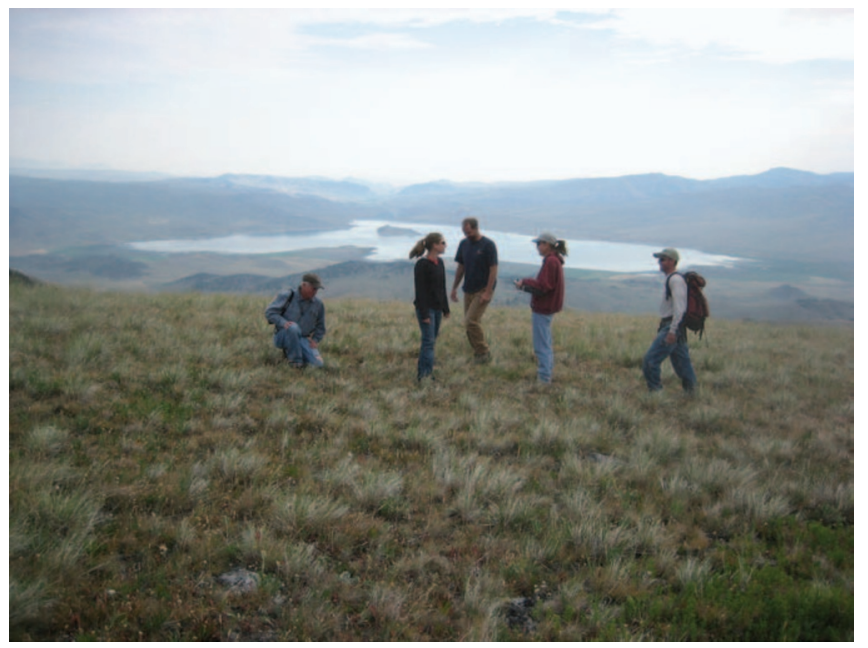

Red Rock Watershed Assessment interdisciplinary team, August 2007. 


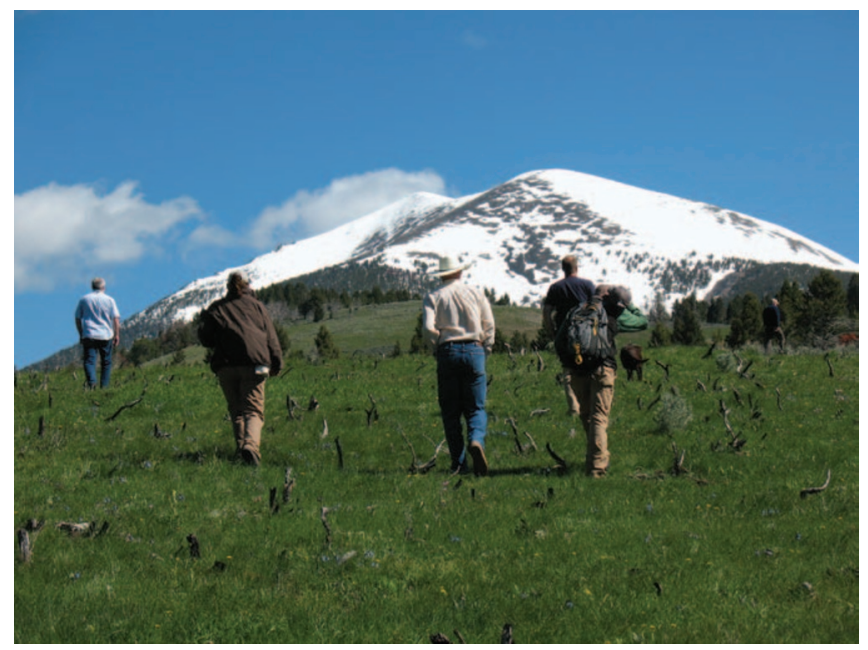

East Grasshopper Watershed Assessment interdisciplinary team, August 2011.

versity. The IDT's Biodiversity ratings rely heavily on their upland and riparian health ratings. It is not uncommon for a single allotment to have multiple streams and key upland sites with different IDT ratings at each site. When this occurs, the scope and scale of those resources that are meeting or not meeting standards must be considered by the authorized officer when determining whether the biodiversity standard is being met. It is acceptable for an allotment to have a failing stream reach or upland site and still have a PFC rating for biodiversity when the scope and scale of the reach or upland that failed are considered. Likewise, a noxious weed infestation or a beetle-damaged conifer stand may cause the allotment to fail the biodiversity standard, even though all uplands and riparian areas in the allotment are PFC. The importance of a cohesive IDT is most apparent when rating the complex biodiversity standard. Time spent visiting key resource areas and reviewing historic monitoring sites, as a team, leads to a more-complete knowledge of the resource and helps the IDT accurately rate the biodiversity standard and provide information to the authorized officer, so that the officer can make an informed decision. Generally, the ecological processes within an allotment must be functioning properly to meet the biodiversity standard.

\section{Assessment Report and Determination}

Once the field work is completed, the IDT writes an Assessment Report documenting its findings. This report is given to the authorized officer, who then makes the Authorized Officer's Determination as to whether or not BLM standards are met on each allotment. If standards are not met, and the cause is within the authorized officer's control, alternatives are developed to improve resource conditions. If standards are not met, but the cause is outside the authorized officer's control, BLM may not have the authority to make changes to improve the resource. Normally, the Assessment Report is about 70 pages long and is completed by December 31 of each year.

\section{Environmental Assessment}

The National Environmental Policy Act of 1969 requires federal agencies to ensure that environmental factors are weighted equally when compared with other factors in the decision-making process. The EA is the part of the Watershed Assessment process in which the long days in the field and the lively team discussions of resource conditions become so valuable. The on-the-ground experience of the entire IDT and the in-depth understanding of existing environmental conditions and the relationships between allotments and the entire watershed make completing a more-thorough EA possible.

The immediate focus of the EA is to identify alternative actions and analyze the effects of those proposed actions, but the ultimate objective is to improve resource conditions and enhance biodiversity on allotments where land-health standards were not being met. Within the EA, alternative actions are developed to address resource concerns in coordination with livestock permittees, other agencies, conservation groups, and the interested public. This includes alternatives for forest, woodland, and rangeland health; fish and wildlife habitat; livestock management; fuels conditions; noxious weeds; access; recreational impacts; etc. A watershed monitoring plan is developed with the EA to measure progress toward meeting defined objectives where resource concerns were found, as specified in BLM manual $\mathrm{H}-4180 .{ }^{2}$ Within the EA, the predicted direct, indirect, and cumulative effects of each alternative are analyzed and disclosed. This EA is sent out to affected parties and the interested public and posted to the DFO's Web site. A media release is issued to inform the public that the EA is available for their review, which asks for their comments during a 30-day comment period.

\section{Proposed and Final Decision}

After completing the EA, the authorized officer selects an alternative or alternatives from the EA based on the predicted effects and public input. This carefully chosen alternative becomes the Proposed Decision and is issued with a 15 -day protest period. This proposed decision is issued outside the traditional field season (May 1 to August 31) to prevent specialists from working on litigation and meeting associated legal deadlines during the field season. Protests that are received can be discussed, negotiated, and resolved with the authorized officer before issuing a Final Decision. If no protests are received during the 15 -day protest period, the Proposed Decision becomes the Final Decision with a 30-day appeal period.

If a protest is received in a timely manner, protest points are considered, and a Final Decision is issued with a 30-day appeal period. If an appeal is received, it is forwarded to the Office of Hearings and Appeals (OHA) for review by an administrative law judge. Appeals cannot be resolved by negotiating with the appellant at the BLM Field Office. If BLM does not receive an appeal, or the decision is appealed, but a stay is not granted, the BLM can implement the Final Deci- 
sion. This includes renewing all grazing permits and leases within the watershed for a 10 -year term.

\section{Benefits and Challenges of the Watershed Approach}

When this program-integrated, watershed-level approach was proposed in 2002, some resource specialists assigned to the IDT refused to participate actively. They preferred working on their individual projects/allotments outside the current Watershed Assessment area and thought that those were more important than participating on the IDT. There were other specialists who criticized the IDT process, particularly that the opinions of all the resource specialists were given equal weight, regardless of experience, years of service, or other accolades, when determining rangeland health. These individuals were dealt with swiftly, but professionally, by the DFO's management team, who firmly reminded such individuals that the Watershed Assessment process and associated IDT work was their highest priority.

Even the most-dedicated BLM specialists found that the new watershed approach was drastically different from the previous way of accomplishing things, which had focused more on individual priorities. The DFO's management team noted that the previous approach often focused individual specialists on their highest priority allotments/projects, whereas moderate or lower priority allotments/projects were being neglected. The watershed process has reprioritized the entire IDT on the 10-30 allotments and associated resources in the current Watershed Assessment area. The IDT has found that the moderate- to lower-priority allotments that received little or no attention in the past are, often, the allotments that require that greatest resource improvement. Although it took some time to adjust to the new Watershed Assessment approach, DFO resource specialists have come to realize that assessing land health as an IDT, at the watershed level, is the most efficient way to assess and improve land health and renew term grazing permits/leases.

The efficiency of the Watershed Assessment process is best described by examining the DFO's accomplishments before and after this approach was undertaken. From 1995 to 2002 (an 8-year period), BLM completed 20 grazing permit/lease renewals, nine administrative determinations, and 72 EAs for individual projects. During the 8-year period from 2003 to 2010, using the Watershed Assessment process, the DFO analyzed the following actions/projects in 15 Watershed EAs:

- Allotment Management Plan revisions on 152 of 363 allotments (42\%) and more than 300 term grazing permit/ lease renewals,

- 86 new water developments and 70 water developments rebuilt or abandoned,

- 97 new spring/riparian exclosures or riparian pastures,

- 63 new division or boundary fences,

- 44 fences removed or modified to reduce wildlife collision/ entanglement hazards,

\section{Keys to Watershed Assessment Success}

- Management support/direction

- On-the-ground BLM land review

- IDT specialist participation

- Permittee/lessee participation

- Public participation (transparent process)

- Defining resource issues

- Defining resource concerns

- Developing feasible/realistic solutions

- Defining time frames

- Developing effective monitoring plans

- Planning, patience, and persistence

- six new wildlife guzzlers and five new fish barriers (for managing native trout),

- 28,000 acres of prescribed burns to restore sagebrush habitat and aspen or improve suppression efforts and safety in the wildland/urban interface,

- more than 9,000 acres of timber/salvage harvest to improve forest health and resiliency,

- whitebark pine restoration, management, and protection projects,

- 29 miles of riparian-conifer removal to enhance deeprooted woody riparian species,

- more than 4,000 acres of mowing, seeding, and mechanical treatments to meet various land health and habitat objectives, and

- 20 miles of road designations (opened/closed) changed to improve public access and mitigate resource concerns.

This list of "ready to go," NEPA-compliant projects enables the DFO to fully expend annually budgeted funding and take advantage of additional or short-notice funding that becomes available throughout any given year. Many of these projects have been completed, and most of the AMPs have been fully implemented. In June 2012, the BLM completed and mailed out for public comment two more watershed EAs and the second round of Watershed Assessments will begin next month in the Upper Horse Prairie Watershed. This will give the DFO an opportunity to determine how successful our management changes have been at meeting defined goals and objectives.

It is difficult to fully appreciate the benefits derived from a diverse group of professionals working together as an IDT on a Watershed Assessment. The long days in the field and the many miles logged by the team members gives everyone a better understanding and appreciation of the watershed ecology and cumulative effects within the watershed. It is in this short, but critical, journey from "on-the-ground" field assessment to the development of management alternatives that the heart of the IDT approach is found. Within the IDT, each participant has the ability and, more important, the responsibility to evaluate each resource and make a condition 


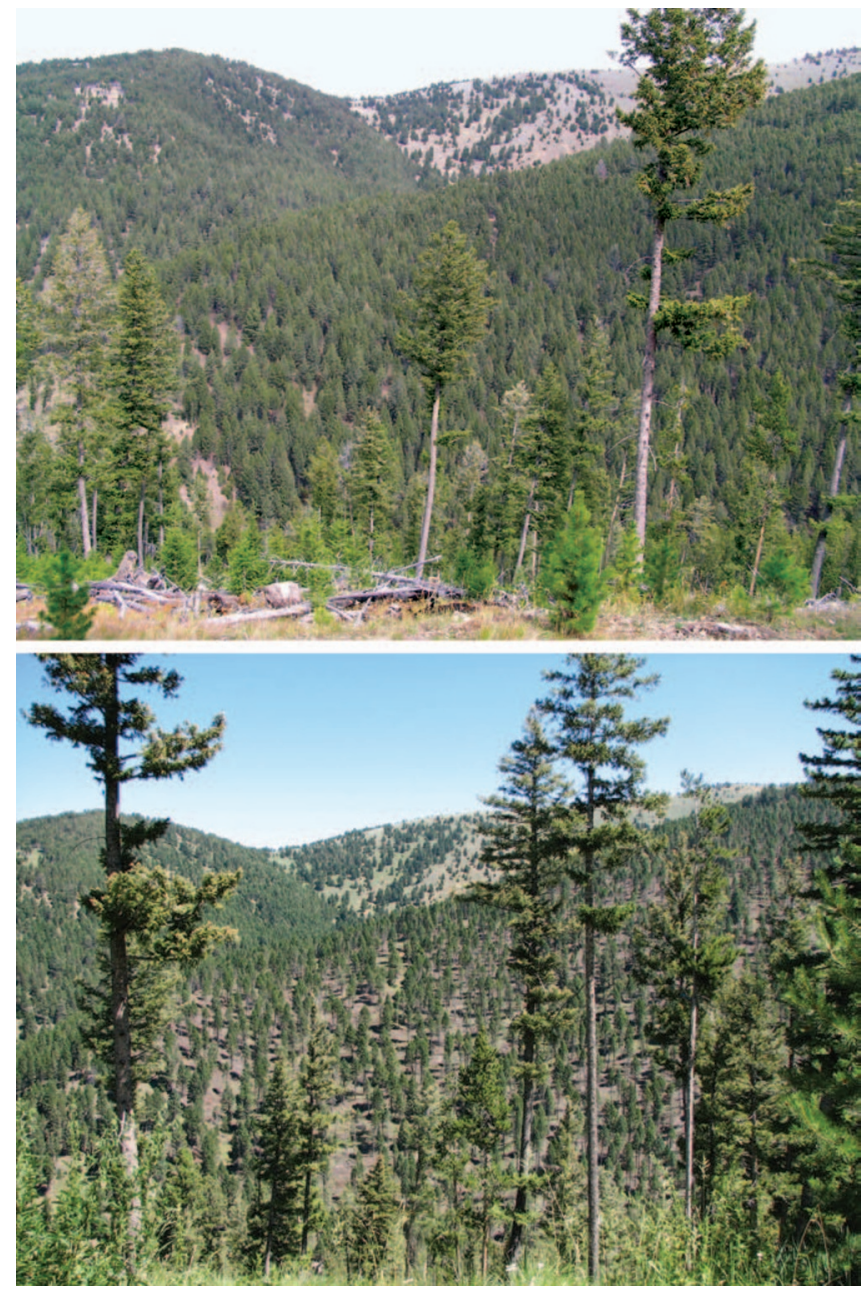

Ruby Watershed Assessment (Watershed Assessment-Douglas-Fir Savannah Restoration project), 2004 pre-treatment (top) and 2007 post-treatment (bottom) comparison.

rating. This responsibility focuses each member and encourages him or her to be engaged in the Watershed Assessment. During a typical discussion of resource conditions, team members are expected to provide journey-level expertise and scientific rational for their observations and ratings, which may influence other team members to reevaluate their own ratings. Ultimately, after everyone's comments are documented, the majority opinion of the IDT's members decides the resource condition rating for each site. Although the rating is decided by a majority of IDT members, all opinions are considered equally, regardless of discipline represented, years of service, or other accolades. Minority opinions are always recorded for consideration by the authorized officer. Within the IDT, and during the assessment process, there is no room for one discipline or program to merely point out a resource problem and another discipline to have the difficult task of mitigating or solving it; it is truly a team effort throughout the process. Ultimately, when a resource fails to meet BLM's land-health standards, the entire IDT is responsible for developing solutions to the problem and mitigating any resource concerns with logical, realistic solutions. When developing and selecting alternatives to improve resource conditions and land health, it is the IDT's recommendations, along with the Authorized Officer decisions, that will lead to improved land health and enhanced biodiversity on the public lands that we are responsible for managing.

It was not until 2008 that DFO realized the indirect benefit of the IDT Watershed Assessment process when it received its first two appeals from the Western Watersheds Project (WWP). In both cases, DFO's decisions were upheld by the OHA, largely because of the thorough Watershed Assessment and NEPA process developed, continually improved upon, and closely followed by the DFO. Of the 15 watersheds assessed during the past decade, three watershedscale Final Decisions and one allotment-specific Final Decision were appealed. Of the three watershed-scale Final Decisions, all were upheld by the OHA. In the allotment-specific appeal, WWP withdrew its appeal of the Final Decision.

To paraphrase a solicitor from the Department of the Interior who has worked closely with the DFO: The strength of the NEPA documents being produced and the decisions being made by the DFO is the interdisciplinary team of professionals who physically visit BLM lands and make informed, professional decisions based on monitoring data to improve public resources within the context of a transparent Watershed Assessment. This IDT-based watershed approach to assessing and improving land health continues to yield benefits far beyond its initial intent.

\section{References}

1. US Department of the Interior. National Wildlife Federation et al. v Bureau of Land Management, 140 IBLA 85, 99 (1997).

2. US Department of the Interior. 2001. Bureau of Land Management handbook H-4180-1: rangeland health standards. Available at: http://www.blm.gov/pgdata/etc/medialib/blm/wo/Information_Resources_Management/ policy/blm_handbook.Par.61484.File.dat/h4180-1.pdf. Accessed 17 January 2012.

Authors are Rangeland Management Specialist, r75martin@blm. gov (Martin), Supervisory Natural Resource Specialist (Fosse), and Rangeland Management Specialist (Thrift), Bureau of Land Management Dillon Field Office, Dillon, MT 59725, USA. 